\title{
Synthesis of Carbonyl and Dicarbonyl Compounds from Organometallic Reagents and \\ N-Imidazolium-N-Methyl Amides and Bis-amides
}

\author{
María A. de las Heras, Juan J. Vaquero, José L. García Navio, Julio Alvarez-Builla* \\ Departamento de Química Orgánica, Universidad de Alcalá, 28871-Alcalá de Henares, Madrid. Spain
}

\begin{abstract}
A new method for the synthesis of selective acylating agents is described from the reaction of carboxylic acids with 3-methyl-1-methylamino- $3 \mathrm{H}$-imidazol-1-ium salts in the presence of appropriate coupling reagents. The amides and bis-amides thus prepared reacted selectively with organometallics to afford ketones and diketones and with DIBAL $H$ to give aldehydes and dialdehydes in high yields.

Copyright 우 1996 Elsevier Science Ltd
\end{abstract}

\section{Introduction}

Work in our laboratory over recent years has demonstrated that aminides 1 can be the origin of a variety of useful reagents. Thus, for example, they can be converted into chlorochromate imidazolium amides 2 , which are mild and selective oxidants for benzylic and allylic alcohols. ${ }^{1}$ Alternatively, $\mathrm{N}$-methylation gives amides $\mathbf{3}$, that act as selective acylating agents, which on reaction with organolithium or Grignard reagents, can generate different ketones in high yields. ${ }^{2}$ Moreover, 3 can be reduced with diisobutylaluminium hydride (DIBALH) to give aldehydes. ${ }^{3}$ In the last two methods, the resulting 3-methyl-1-methylamino-3H-imidazol-1-ium salt 5 can be easily recovered and recycled, thus making the procedures both cheap and clean.

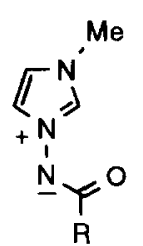

1

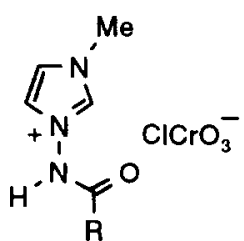

2
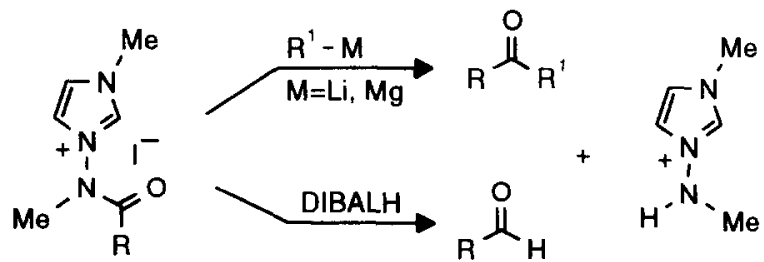

3

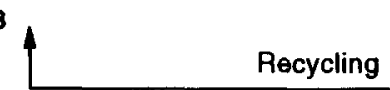

5

\section{Scheme 1}


We believe that the formation of ketones from 3 in good to excellent yields, is a result of the activation of the carbonyl group by initial metalation on the 2-position of the imidazolium ring, followed by formation of a stable intermediate after addition of the organometallic reagent. ${ }^{2}$

Although the preparation of ketones and aldehydes from 3 seems to be very general, producing similar or even better yields than those obtained from Weinreb's amide, ${ }^{4.5}$ the synthesis of the aminide 1 or the amide 3 precursors, prepared by reacting the corresponding acyl chloride with 1-amino-3-methyl-3H-imidazol-1-ium salt 4 or 3-methyl1-methylamino-3H-imidazol-1-ium salts 5 , proved to be troublesome in some cases. We have recently however, improved the synthesis of both 1 and 3 by reacting saits 4 or 5 with carboxylic acids in the presence of suitable condensing agents. This results in a considerable expansion of the potential utility of amides 3 and bis-amides 8 whose preparation from carboxylic and dicarboxylic acids is now reported, along with their application in the synthesis of carbonyl and dicarbonyl compounds, by either reacting with organometallics or with reducing agents.

\section{Results and Discussion}

Synthesis of $\mathrm{N}$-imidazolium- $\mathrm{N}$-methyl amides and bis-amides from carboxylic and dicarboxylic acids. Our original synthesis of 3 involved the reaction of acylchlorides with 4 , under two-phase conditions, followed by methylation of the resulting aminide $1 .{ }^{2}$ In some cases improved yields of 3 could be achieved by direct condensation of the salt 5 with acyl chlorides. Although acceptable yields (45-72\%) were obtained with a wide range of amides, the preparation of the aminide or amide failed with phenylacetyl chloride, and low yields resulted when the condensation was carried out with sterically hindered halides such as pivaloyl chloride.

Based on previous experience, we reasoned that the use of acyl chlorides could be circumvented by developing a direct reaction between $\mathbf{4}$ or 5 and a carboxylic acid using an appropriate coupling agent. Although initially we were concerned about the success of this approach due to the poor nucleophilicity of the amino group, we were encouraged by the numerous literature examples of different couplings agents with wide application in peptide chemistry. In fact we found that in the presence of dicyclohexylcarbodiimide (DCC) and dimethylaminopyridine (DMAP), ${ }^{6} 4$ reacted with benzoic acid to produce the desired aminide 1a in $70 \%$ yield, and that the use of diethylphosphonyl chloride (DEPC) ${ }^{7}$ and triethylamine instead of DCC enhanced the yield of $1 \mathrm{a}$ to $74 \%$. Using the same agents, the condensation between benzoic acid and 5 was also successful with the amide 3 being obtained in $72 \%$ (DCC) and 80\% (DEPC) yields. Employing these conditions, we next investigated the versatility of the method with other various carboxylic acids and we found that the coupling of $\mathbf{4}$ or 5 with either aliphatic or $\alpha$, $\beta$-unsaturated acids failed in the presence of either of DCC or DEPC. A recent report by Kimura and co-workers ${ }^{8}$ in which the coupling of amines with carboxylic acids was achieved via activation of the amine with 5-methyl-2-chloro-3-phenyl2,3-dihydro-1,3,4,2-oxadiazaphosphole (6) seemed to offer a possible solution. As expected, in the presence of 6 , the reaction of 4 and 5 with 4-phenylbutanoic acid gave the desired condensation products $1 \mathrm{~b}$ and $3 \mathrm{~b}$ in $83 \%$ and $78 \%$ yield respectively. 


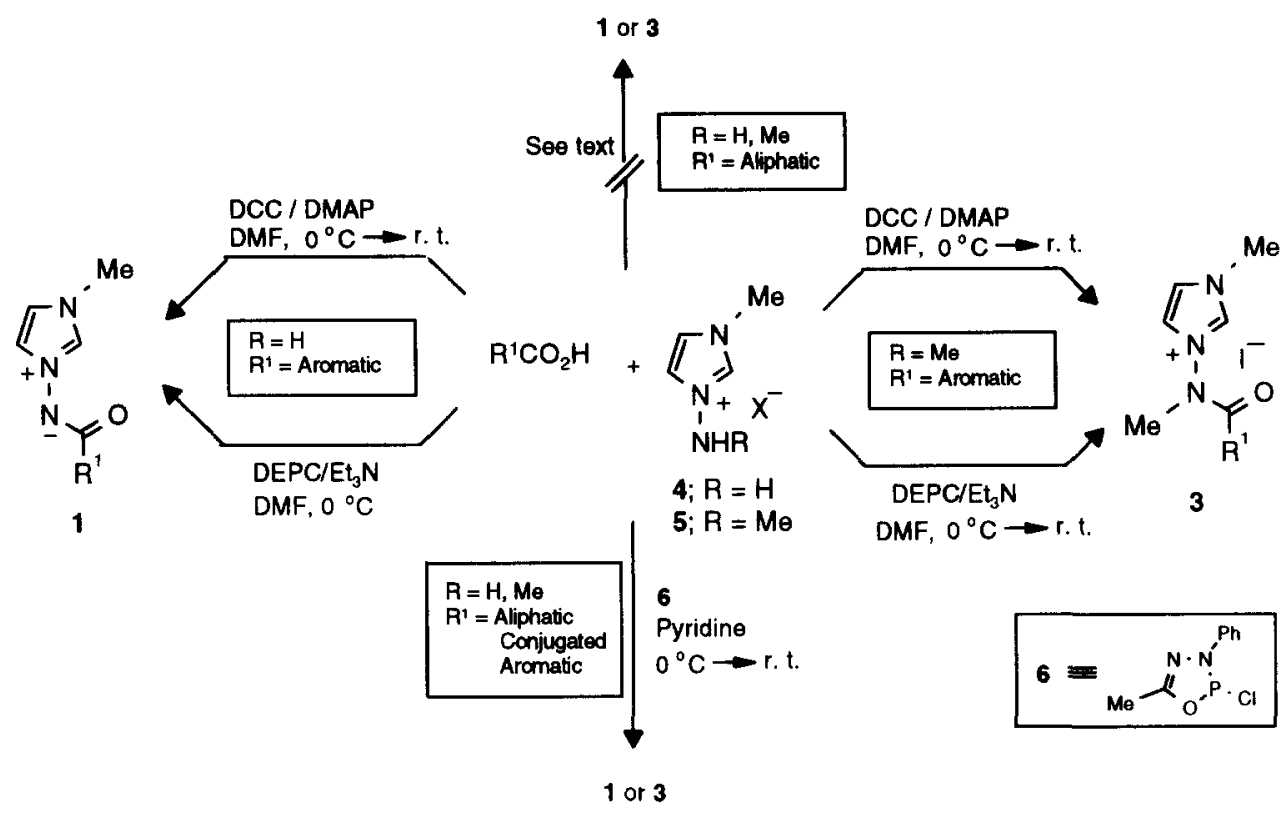

Scheme 2

Similarly, when other carboxylic acids, including $\alpha, \beta$-unsaturated (Table 1, entry 14) and heteroaromatic acids (Table 1, entries 15 and 16) were used, the corresponding condensation products $3 \mathrm{c}$-h were obtained in $70-89 \%$ yields (Table 1). It should be noted that this method also provided easy access to the amide $3 \mathrm{c}$ in $70 \%$ yield, which, as indicated above (Scheme 2), was not accessible from the acid chloride, whilst the condensation of pivaloic acid with 5 gave $3 d$ in $75 \%$ yield.

The successful methodology developed for the generation of $\mathbf{3}$ directly from carboxylic acids, was then applied to a high-yielding synthesis of bis-amides 8 by reacting 4 and 5 with aromatic or aliphatic dicarboxylic acids. The precursor diaminides 7 showed poor stability on standing and were methylated in situ without isolation (Scheme 3).

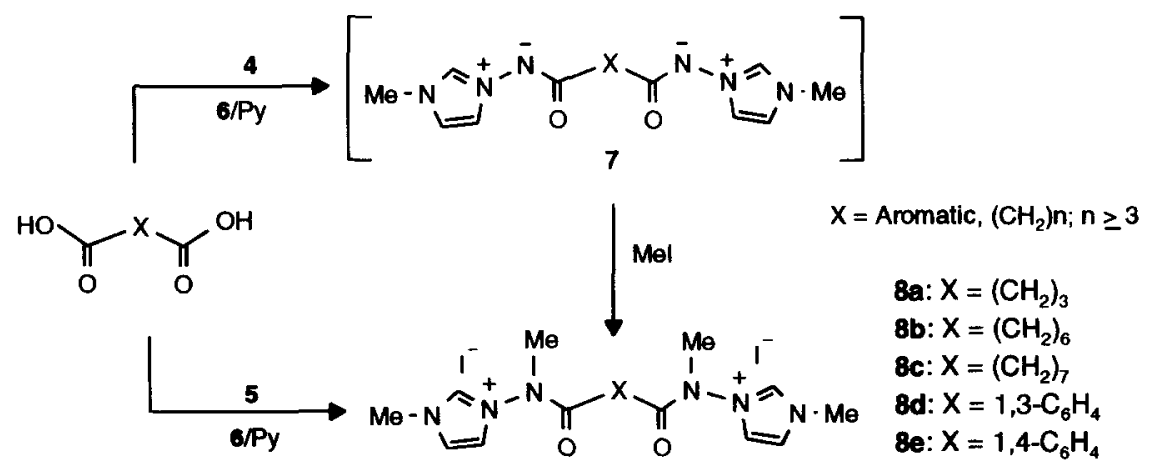

Scheme 3 
Table 1. Synthesis of imidazolium aminides 1 and amides 3

\begin{tabular}{|c|c|c|c|c|c|}
\hline Entry & $\mathbf{R}$ & $\mathbf{R}^{1}$ & Method $^{2}$ & Compound $^{b}$ & Yield (\%) \\
\hline I & $\mathrm{H}$ & $\mathrm{C}_{6} \mathrm{H}_{5}$ & $\bar{A}$ & $1 \mathrm{a}[2]$ & 70 \\
\hline 2 & $\mathbf{H}$ & $\mathrm{C}_{6} \mathrm{H}_{5}$ & B & $1 \mathrm{a}$ & 74 \\
\hline 3 & $\mathrm{H}$ & $\mathrm{C}_{6} \mathrm{H}_{5}$ & C & $1 \mathbf{a}$ & 76 \\
\hline 4 & $\mathrm{Me}$ & $\mathrm{C}_{6} \mathrm{H}_{5}$ & A & $3 \mathrm{a}[2]$ & 72 \\
\hline 5 & $\mathrm{Me}$ & $\mathrm{C}_{6} \mathrm{H}_{5}$ & B & $\mathbf{3 a}$ & 80 \\
\hline 6 & $\mathrm{Me}$ & $\mathrm{C}_{6} \mathrm{H}_{5}$ & $\mathrm{C}$ & $\mathbf{3 a}$ & 89 \\
\hline 7 & $\mathbf{H}$ & $\mathrm{C}_{6} \mathrm{H}_{5}-\left(\mathrm{CH}_{2}\right)_{3}$ & $A$ or $B$ & $1 \mathbf{b}$ & 0 \\
\hline 8 & $\mathrm{H}$ & $\mathrm{C}_{6} \mathrm{H}_{5}-\left(\mathrm{CH}_{2}\right)_{3}$ & C & $\mathbf{1 b}$ & 83 \\
\hline 9 & $\mathrm{Me}$ & $\mathrm{C}_{6} \mathrm{H}_{5}-\left(\mathrm{CH}_{2}\right)_{3}$ & $A$ or $B$ & $\mathbf{3 b}$ & 0 \\
\hline 10 & $\mathbf{M e}$ & $\mathrm{C}_{6} \mathrm{H}_{5}-\left(\mathrm{CH}_{2}\right)_{3}$ & c & $\mathbf{3 b}$ & 78 \\
\hline 11 & $\mathrm{Me}$ & $\mathrm{C}_{6} \mathrm{H}_{5}-\mathrm{CH}_{2}$ & C & $3 c$ & 70 \\
\hline 12 & Me & $\left(\mathrm{CH}_{3}\right)_{3} \mathrm{C}$ & C & 3d & 75 \\
\hline 13 & $\mathrm{Me}$ & $\mathrm{CH}_{3}\left(\mathrm{CH}_{2}\right)_{14}$ & C & $3 \mathbf{e}$ & 85 \\
\hline 14 & $\mathrm{Me}$ & $\mathrm{C}_{6} \mathrm{H}_{5}-\mathrm{CH}=\mathrm{CH}$ & $\mathrm{C}$ & $3 f[2]$ & 83 \\
\hline 15 & Me & 2-Thienyl & C & $3 g[2]$ & 72 \\
\hline 16 & $\mathrm{Me}$ & 1-Isoquinolyl & $\mathrm{C}$ & 3h & 70 \\
\hline 17 & Me & $\mathrm{C}_{6} \mathrm{H}_{5}-\mathrm{CO}-\left(\mathrm{CH}_{2}\right)_{3}$ & $\mathrm{C}$ & $3 \mathbf{i}$ & 73 \\
\hline 18 & $\mathrm{Me}$ & & C & $\mathbf{3 j}$ & 77 \\
\hline
\end{tabular}

${ }^{2}$ Meshod A: DCC/DMAP/DMF, $0^{\circ} \mathrm{C} \rightarrow$ r.t.; Method B: DEPC/Et 3 N/DMF, $0{ }^{\circ} \mathrm{C} \rightarrow$ r.t.; Method C: 6/pyridine, $0{ }^{\circ} \mathrm{C} \rightarrow$ r.t.

${ }^{\mathrm{b}}$ The synthesis of aminide $1 \mathrm{a}$ and amides $3 \mathrm{a}, 3 \mathrm{f}$ and $3 \mathrm{~g}$ are described in the reference given in brackets.

Unfortunately, only unreacted starting materials or complex mixtures were obtained in the reactions with oxalic, malonic and succinic acids, presumably because of the instability generated by the electrostatic repulsion originating from the proximity of the two imidazolium rings in the expected final compounds $\mathbf{7}$ and $\mathbf{8}$, and the decarboxylation processes supposedly associated with the monoacyl derivatives produced as intermediates. This is a limitation of this methodology which precludes the preparation of useful 1,2-, 1,3- and 1,4-dicarbonyl compounds ${ }^{9}$ (see below).

Synthesis of Carbonyl and Dicarbonyl Compounds. Using the reported procedure, metalation of the new salts $3 \mathrm{c}$-d in THF, followed by addition of an organometallic reagent (organolithium or Grignard reagent) to the intermediate 9, led to a fast and clean route to benzyl- and tert-butyl ketones 12. Particularly noteworthy is the high yield of di-tert-butyl ketone 12e obtained (73\%) (Table 2, entry 5) thus highlighting another of advantages of the 
methodology in the synthesis of ketones. The amides 3 were also selectively transformed into the corresponding aldehydes 13, by reducing with diisobutylaluminium hydride (DIBALH) in THF. Other hydride donors such as $\mathrm{LiAlH}_{4}, \mathrm{NaBH}_{4}$ and $\mathrm{LiAlH}(\mathrm{OEt})_{3}$ were also tested but the aldehyde was accompanied in all cases by variable amounts of the corresponding $\mathrm{N}$-methylamide as a result of the cleavage of the $\mathrm{N}$-N bond. When $\mathrm{LiAlH}_{4}$ was used, reduction of the imidazolium moiety to dihydroimidazole derivatives also occurred to a minor extent. In practice, selective reduction appears to be an efficient method for the conversion of carboxylic acids into aldehydes via the 1-(N-acylamino-N-methyl)-3-methyl-3H-imidazol-1-ium salts.

In an effort to obtain $\alpha$-alkylated ketones, the methodology was applied to enolizable amides. However, activation of the carbonyl group in the metalated intermediate 9 and the concomitant facile addition of one equivalent of either organolithium or Grignard reagents failed to give the desired compounds, with ketones being formed even in the presence of large excesses of the organometallic reagent. We have now found that formation of the metalated intermediate can also be easily achieved by using LDA (1.05 equiv) and treatment of the enolizable amides $\mathbf{3 c}$ and $\mathbf{3 j}$ with 2.1 equiv of LDA in THF, followed by addition of an electrophile (alkyl halide or aldehyde) and 1 equiv of the organolithium led, after quenching with $\mathrm{NH}_{4} \mathrm{Cl}$, to the $\alpha$-alkylated ketones 14 (Table 2, entries 18-22) presumably via the intermediates 10 and 11 (Scheme 4).

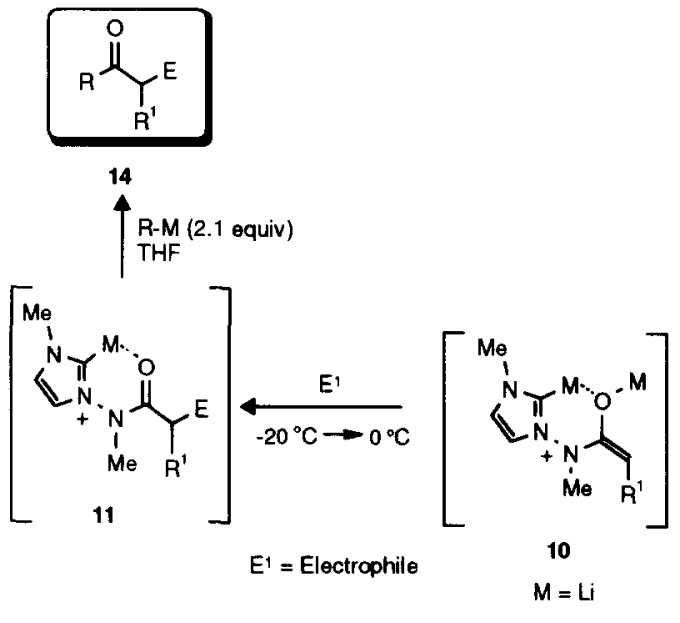

Scheme 4
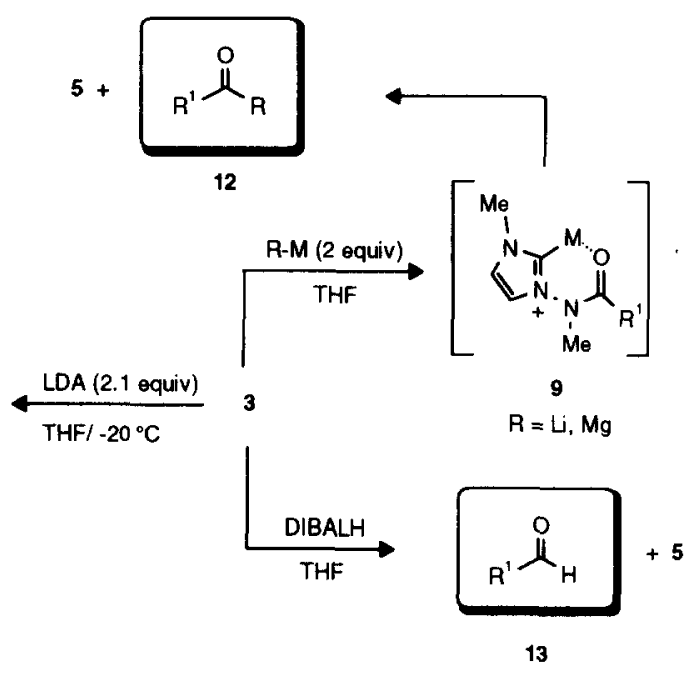

When 8 was reacted with 4 equiv of an organometallic reagent, or with LDA (2.1 equiv) followed by the organometallic reagent ( 2 equiv), yields between $76-82 \%$ of pure diketones 15 were obtained (Table 3 ). The transformation of 8 into the corresponding dialdehydes 16 was also carried out with DIBALH, although in this 
Table 2. Synthesis of ketones and aldehydes from imidazolium amides 3

\begin{tabular}{|c|c|c|c|c|c|}
\hline Entry & $\mathbf{R}$ & $\mathbf{R}^{1}$ & E & Compound ${ }^{a}$ & Yield (\%) \\
\hline 1 & $4-\mathrm{CH}_{3}-\mathrm{C}_{6} \mathrm{H}_{4}$ & $\mathrm{C}_{6} \mathrm{H}_{5}-\mathrm{CH}_{2}$ & -- & $12 \mathrm{a}[11]$ & 78 \\
\hline 2 & $\mathrm{CH}_{3}-\left(\mathrm{CH}_{2}\right)_{3}$ & $\mathrm{C}_{6} \mathrm{H}_{5}-\mathrm{CH}_{2}$ & -- & $12 \mathrm{~b}[12]$ & 82 \\
\hline 3 & $\mathrm{C}_{6} \mathrm{H}_{5}$ & $\left(\mathrm{CH}_{3}\right)_{3} \mathrm{C}$ & -- & $12 c[13]$ & 78 \\
\hline 4 & $\mathrm{CH}_{3}-\left(\mathrm{CH}_{2}\right)_{14}$ & $\left(\mathrm{CH}_{3}\right)_{3} \mathrm{C}$ & -- & $12 d$ & 68 \\
\hline 5 & $\left(\mathrm{CH}_{3}\right)_{3} \mathrm{C}$ & $\left(\mathrm{CH}_{3}\right)_{3} \mathrm{C}$ & -- & $12 e[14]$ & 73 \\
\hline 6 & 2-Thienyl & $\left(\mathrm{CH}_{3}\right)_{3} \mathrm{C}$ & -- & $12 f[15]$ & 76 \\
\hline 7 & $\mathrm{CH}_{3} \mathrm{C} \equiv \mathrm{C}$ & $\left(\mathrm{CH}_{3}\right)_{3} \mathrm{C}$ & -- & $12 \mathrm{~g}[16]$ & 70 \\
\hline 8 & $\mathrm{C}_{6} \mathrm{H}_{5}$ &. & - & $13 \mathbf{a}$ & 77 \\
\hline 9 & $4-\mathrm{O}_{2} \mathrm{~N}-\mathrm{C}_{6} \mathrm{H}_{4}$ &. & -. & $13 \mathbf{b}$ & 78 \\
\hline 10 & $4-\mathrm{Cl}-\mathrm{C}_{6} \mathrm{H}_{4}$ & - & - & $13 c$ & 76 \\
\hline 11 & $4-\mathrm{CH}_{3}-\mathrm{C}_{6} \mathrm{H}_{4}$ & - & - & 13d & 80 \\
\hline 12 & $\mathrm{C}_{6} \mathrm{H}_{5}-\mathrm{CH}=\mathrm{CH}$ & - & - & $13 e$ & 80 \\
\hline 13 & 2-Thienyl & - & -- & $13 f$ & 75 \\
\hline 14 & $\mathrm{CH}_{3}\left(\mathrm{CH}_{2}\right)_{14}$ & - & - & $13 g$ & 83 \\
\hline 15 & $\mathrm{CH}_{2}=\mathrm{CH}-\left(\mathrm{CH}_{2}\right)_{8}$ & -- & -- & 13h & 69 \\
\hline 16 & Cyclohexyl & - & - & 13i & 72 \\
\hline 17 & $\left(\mathrm{CH}_{3}\right)_{3} \mathrm{C}$ & - & - & $13 \mathbf{j}$ & 70 \\
\hline 18 & $\mathrm{C}_{6} \mathrm{H}_{5}$ & $\mathrm{C}_{6} \mathrm{H}_{5}$ & $\mathrm{CH}_{3}$ & 14a[17] & 65 \\
\hline 19 & $\mathrm{CH}_{3}-\mathrm{C} \equiv \mathrm{C}$ & $\mathrm{C}_{6} \mathrm{H}_{5}$ & $\mathrm{C}_{6} \mathrm{H}_{5} \mathrm{CH}_{2}$ & $14 b$ & 69 \\
\hline 20 & $\left(\mathrm{CH}_{3}\right)_{3} \mathrm{C}$ & $\mathrm{C}_{6} \mathrm{H}_{5}$ & $\mathrm{CH}_{2}=\mathrm{CH}-\mathrm{CH}_{2}$ & $14 c$ & 52 \\
\hline 21 & 4- $\mathrm{CH}_{3}-\mathrm{C}_{6} \mathrm{H}_{4}$ & 2-Thienyl & $\mathrm{CH}_{3}$ & $14 d$ & 63 \\
\hline 22 & $\mathrm{CH}_{3}-\mathrm{C} \equiv \mathrm{C}$ & 2-Thienyl & 4- $\mathrm{CH}_{3} \mathrm{O}-\mathrm{C}_{6} \mathrm{H}_{4}-\mathrm{CHOH}$ & $14 e$ & 66 \\
\hline
\end{tabular}

a Ketones 12 and 14 and aldehydes 13 were characterised by comparison their analytical and spectral data with authentic samples, with commercially available compounds or with those reported in the literature (references in brackets)

case the reaction had to be performed in $\mathrm{CH}_{2} \mathrm{Cl}_{2}$ as the bis-amides 8 are more soluble in this solvent than in THF (Scheme 5). In the latter solvent yields of isolated dialdehyde are much lower, most likely because of the insolubility of the bis-amides.

The sequential addition of two different organometallic species, which should lead to unsymmetrically substituted diketones was also attempted under various conditions. The addition of 1 equiv of PhLi to previously metalated $8 \mathbf{a}$ (LDA, 2.1 equiv) followed by the addition of 1 equiv of BuLi yielded a mixture of symmetrical and unsymmetrical 
Table 3. Synthesis of diketones 15 and dialdehydes 16 from bis-amides 8

\begin{tabular}{lllll}
\hline Entry & $\mathbf{X}$ & $\mathbf{R}$ & Compound & Yield (\%) \\
\hline 1 & $\left(\mathrm{CH}_{2}\right)_{3}$ & $\mathrm{C}_{6} \mathrm{H}_{5}-\mathrm{CH}=\mathrm{CH}$ & $\mathbf{1 5 a}$ & 86 \\
2 & $1,4-\mathrm{C}_{6} \mathrm{H}_{4}$ & $4-\mathrm{CH}_{3} \mathrm{C}_{6} \mathrm{H}_{5}$ & $\mathbf{1 5 b}[18]$ & 85 \\
3 & $\left(\mathrm{CH}_{2}\right)_{6}$ & $4-\mathrm{CH}_{3} \mathrm{C}_{6} \mathrm{H}_{5}$ & $\mathbf{1 5 c}[19]$ & 80 \\
4 & $1,3-\mathrm{C}_{6} \mathrm{H}_{4}$ & $\mathrm{CH}_{3}\left(\mathrm{CH}_{2}\right)_{3}$ & $\mathbf{1 5 d}[20]$ & 82 \\
5 & $\left(\mathrm{CH}_{2}\right)_{3}$ & $\mathrm{CH}_{3}\left(\mathrm{CH}_{2}\right)_{3}$ & $\mathbf{1 5 e}[21]$ & 88 \\
6 & $\left(\mathrm{CH}_{2}\right)_{3}$ & - & $\mathbf{1 6 a}$ & 72 \\
7 & $\left(\mathrm{CH}_{2}\right)_{6}$ &.- & $\mathbf{1 6 b}$ & 77 \\
8 & $\left(\mathrm{CH}_{2}\right)_{7}$ & - & $\mathbf{1 6 c}$ & 78 \\
9 & $1,3-\mathrm{C}_{6} \mathrm{H}_{4}$ & $\cdots$ & $\mathbf{1 6 d}$ & 82 \\
\hline
\end{tabular}

${ }^{2}$ Diketones 15 and dialdehydes 16 were characterised by comparison their analytical and spectral data with authentic samples, with commercially available compounds or with those reported in the literature (references in brackets)

ketones, with double addition of $\mathrm{PhLi}$ to $8 \mathrm{a}$ being the preferred reaction. Unfortunately, even the most soluble bisamide $\mathbf{8 c}$ was insufficiently soluble in all solvents suitable for Grignard or organolithium reagents, to allow us to carry out the reaction under homogeneous conditions, in which production of unsymmetrically substituted diketones is favoured.

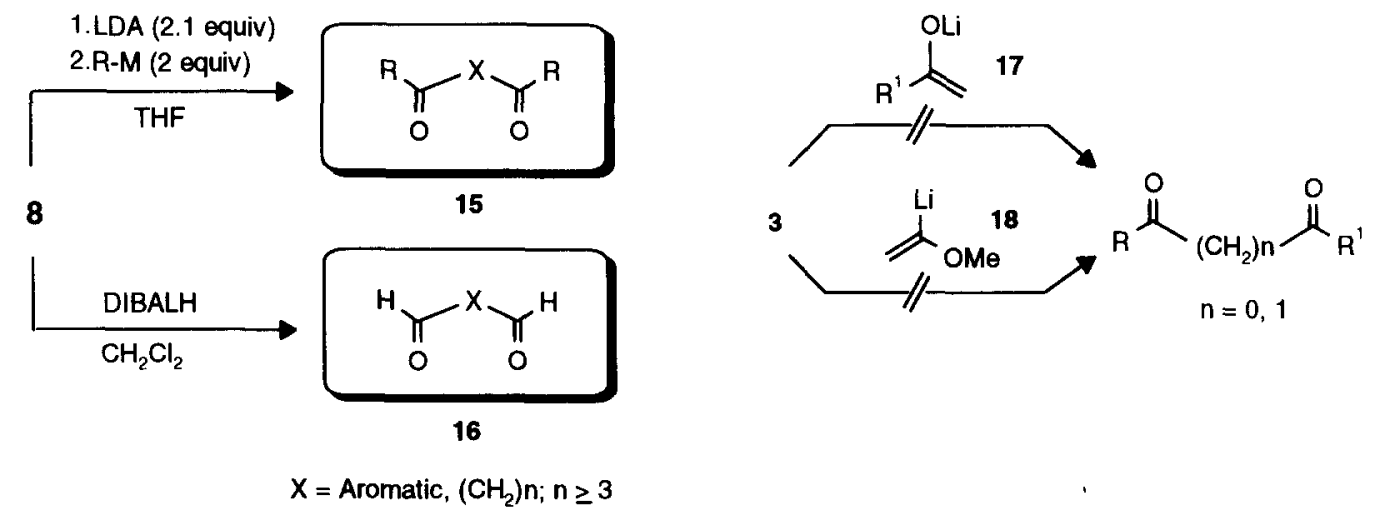

\section{Scheme 5}

The above mentioned failure to obtain bis-amides from oxalic and malonic acids or the corresponding acyl chlorides led us to explore an alternative strategy to obtain 1,2- and 1,3-diketones, in which lithium enolates 17 and 18 were reacted with 3 . Thus a non-enolizable amide such as 1-(N-benzoyl-N-methylamino)-3-methyl-3H-imidazol1-ium iodide was metalated as previously indicated (LDA, 1.05 equiv, $-78^{\circ} \mathrm{C}$ ), and the lithium enolate 17 then 
added. However, the expected reaction was not observed and the amide was extensively recovered after quenching. At higher temperatures $\left(-20^{\circ} \mathrm{C}\right.$ to r.t.) the enolate was also unreactive or gave self-condensation products. Similar results were obtained with the enolate 18.

In conclusion, the direct synthesis of $\mathrm{N}$-imidazolium- $\mathrm{N}$-methyl amides and bis-amides from carboxylic acids and aminoimidazolium salts represents an improvement over the procedure via acyl halides. Furthermore, the method allowed easy access to 3-methyl-1-(methylphenylacetylamino)-3H-imidazol-1-ium iodide which was not accessible from phenylacetyl chloride. These amides reacted with DIBALH to give aldehydes and with organometallic reagents to afford benzyl and tert-butyl ketones. The enolization of benzyl- and 2-thienylmethyl amides followed by sequential addition of electrophiles and organolithium reagents afforded the alkylated ketones after quenching. Imidazolium bis-amides reacted with DIBALH and organometallics affording dialdehydes and diketones respectively, although the lack of accessibility to some bis-amides precluded the preparation of 1,2-, 1,3- and 1,4-dicarbonyls. In all cases the resulting 3-methyl-1-methylamino-3H-imidazol-1-ium salt was easily recovered and recycled, thus making the methodology cheap and clean.

\section{Experimental Section}

Melting points were determined on a Buchi SMP-20 apparatus and are uncorrected. ${ }^{~} \mathrm{H}$ NMR were recorded on a Varian Unity 300 spectrometer were referenced to TMS. IR spectra were obtained on a Perkin-Elmer 1310 spectrophotometer. Microanalyses were performed on a Heraeus CHN Rapid analyzer. MS were obtained on a Hewlett-Packard 5988 A spectrometer. Chromatography was performed on silica gel 60 (230-400 meshs). All reagents were obtained from commercial sources. THF was distilled from sodium-benzophenone. $\mathrm{CH}_{2} \mathrm{Cl}_{2}$ was dried from $\mathrm{P}_{2} \mathrm{O}_{5}$. All solutions of organometallic reagents were titrated before using. Reactions involving organometallics were carried out under an argon atmosphere, in glassware that had been dried at $100^{\circ} \mathrm{C}$ for at least $3 \mathrm{~h}$. LDA was used as a commercial $2 \mathrm{M}$ solution in THF and organometallic reagents were used as commercial solutions in THF, $\mathrm{Et}_{2} \mathrm{O}$ or prepared according to standard procedures. 1-Amino-3-methyl-3H-imidazol-1-ium mesitylenesulfonate (4) and 3-methyl-1-methylamino imidazolium iodide (5) were prepared as previously described. ${ }^{2}$

Synthesis of aminides 1 and amides 3. General procedure. Method A. A mixture of 1-amino-3-methyl-3Himidazol-1-ium mesitylenesulfonate $4(1 \mathrm{~g}, 3.36 \mathrm{mmol})$ or 3-methyl-1-methylamino-3H-imidazol-1-ium iodide 5 $(0.80 \mathrm{~g}, 3.36 \mathrm{mmol})$, the corresponding carboxylic acid $(2.8 \mathrm{mmol})$ and DMAP $(34 \mathrm{mg}, 0.28 \mathrm{mmol})$ was dissolved in dry $\mathrm{CH}_{2} \mathrm{Cl}_{2}(4 \mathrm{~mL})$ and chilled $\left(0^{\circ} \mathrm{C}\right)$. Then, a solution of $\mathrm{DCC}(0.63 \mathrm{~g}, 3.1 \mathrm{mmol})$ in dry $\mathrm{CH}_{2} \mathrm{Cl}_{2}(2 \mathrm{~mL})$ was added. After $15 \mathrm{~min}$ at $0^{\circ} \mathrm{C}$, the reaction mixture was then stirred at room temperature overnight. Removal of the urea by filtration and concentration of the filtrate gave a residue which was triturated with EtOAc affording the corresponding aminide or amide.

Method B. To a stirred mixture of $4(1 \mathrm{~g}, 3.36 \mathrm{mmol})$ or $5(0.80 \mathrm{~g}, 3.36 \mathrm{mmol})$ and the corresponding 
carboxylic acid $(3.05 \mathrm{mmol})$, in DMF $(4 \mathrm{~mL})$ at $0^{\circ} \mathrm{C}$, triethylamine $(7.05 \mathrm{mmol})$ was slowly added and stirring was maintained at $0^{\circ} \mathrm{C}$ for $30 \mathrm{~min}$ then at room temperature overnight. The solvent was then eliminated under reduced pressure and the residue was worked-up as indicated in method $\mathrm{A}$.

Method C. 5-Methyl-2-chloro-3-phenyl-2,3-dihydro-1,3,4,2-oxadiazaphosphole 6 (0.72 g, $3.36 \mathrm{mmol})$ was added dropwise with stirring at $0^{\circ} \mathrm{C}$ to a mixture of the corresponding carboxylic acid (3.36 mmol) and 4 (1 $\mathrm{g}, 3.36$ mmol) or $5(0.80 \mathrm{~g}, 3.36 \mathrm{mmol})$, in pyridine $(7.5 \mathrm{~mL})$. The reaction mixture was stirred at room temperature overnight and then an aqueous solution of $\mathrm{K}_{2} \mathrm{CO}_{3}(0.92 \mathrm{~g}, 6.7 \mathrm{mmol})$ was added dropwise. The solvent was evaporated under reduced pressure, $\mathrm{CH}_{2} \mathrm{Cl}_{2}$ was added and the mixture was filtered through celite and the filtrate was concentrated under reduced pressure. The residue was purified by column chromatography (acetone:MeOH, $5: 1)$ giving pure aminides or amides.

The synthesis of 1-(benzoylamino)-3-methyl-3H-imidazol-1-ium hydroxide inner salt (1a), 1-(benzoylmethylamino)-3-methyl-3H-imidazol-1-ium iodide (3a), 1-(cinamoylmethylamino)-3-methyl-3H-imidazol-1-ium iodide (3f) and 3-methyl-1-[methyl(2-thiophenecarbonyl)amino]-3H-imidazol-1-ium iodide (3g) are described in ref. 2.

3-Methyl-1-[(4-Phenylbutyryl)amino]-3H-imidazol-1-ium hydroxide inner salt (1b). White needles from AcOEt; mp $117-118^{\circ} \mathrm{C}$. IR (KBr) 3143, 3025, 2927, 1578, 1548, 1496, 1452, 1373, 1317, $1136,1029 \mathrm{~cm}^{-1} ;{ }^{1} \mathrm{H}^{-}$ NMR (DMSO-d, $300 \mathrm{MHz}) \delta 9.47(\mathrm{~s}, 1 \mathrm{H}), 7.44(\mathrm{~s}, 1 \mathrm{H}), 7.38(\mathrm{~s}, 1 \mathrm{H}), 7.22-7.27(\mathrm{~m}, 2 \mathrm{H}), 7.11-7.18(\mathrm{~m}, 3 \mathrm{H}), 3.73$ $(\mathrm{s}, 3 \mathrm{H}), 2.55(\mathrm{t}, \mathrm{J}=7.5 \mathrm{~Hz}, 2 \mathrm{H}), 1.99(\mathrm{t}, \mathrm{J}=7.5 \mathrm{~Hz}, 2 \mathrm{H}), 1.78(\mathrm{q}, \mathrm{J}=7.5 \mathrm{~Hz}, 2 \mathrm{H})$ ppm. Anal. Calcd for $\mathrm{C}_{14} \mathrm{H}_{17} \mathrm{~N}_{3} \mathrm{O}: \mathrm{C}, 69.10 ; \mathrm{H}, 7.05, \mathrm{~N} ; 17.28$. Found: $\mathrm{C}, 69.23 ; \mathrm{H}, 7.25 ; \mathrm{N}, 17.63$.

3-Methyl-1-[methyl-(4-phenylbutyryl)amino]-3H-imidazol-1-ium iodide (3b). White powder from acetone; mp 152-153 ${ }^{\circ} \mathrm{C}$. IR (KBr) 2932, 1691, 1632, 1583, 1452, 1381,1187, 1087, $1024 \mathrm{~cm}^{-1} .{ }^{1} \mathrm{H}-\mathrm{NMR}\left(\mathrm{DMSO}-\mathrm{d}_{6}, 300\right.$ $\mathrm{MHz}$ ): $\delta 9.50$ (bs, 1H), 8.09 (bs, $1 \mathrm{H}), 7.81(\mathrm{~s}, 1 \mathrm{H}), 7.12-7.68(\mathrm{~m}, 5 \mathrm{H}), 3.89(\mathrm{~s}, 3 \mathrm{H}), 3.40(\mathrm{bs}, 3 \mathrm{H}), 2.56(\mathrm{~m}, 2 \mathrm{H})$, 2.00-2.30 (m, $2 \mathrm{H}), 1.79(\mathrm{~m}, 2 \mathrm{H})$ ppm. Anal. Calcd for $\mathrm{C}_{15} \mathrm{H}_{20} \mathrm{IN}{ }_{3} \mathrm{O}: \mathrm{C}, 46.75 ; \mathrm{H}, 5.23 ; \mathrm{N}, 10.91$. Found: $\mathrm{C}$, 46.62; $\mathrm{H}, 5.18 ; \mathrm{N}, 10.85$.

3-Methyl-1-(methylphenylacetylamino)-3H-imidazol-1-ium iodide (3c). White prisms from EtOH; mp 131$133^{\circ} \mathrm{C}$. IR(KBr) 3082, 1697, 1582, 1452, $1096 \mathrm{~cm}^{-1} ;{ }^{1} \mathrm{H}-\mathrm{NMR}$ (CD $\left.\mathrm{OD}, 300 \mathrm{MHz}\right): \delta 7.81$ (s, 1H), $7.68(\mathrm{~s}, 1 \mathrm{H})$, 7.27-7.33 (m, $5 \mathrm{H}), 3.94$ (s, 3H), 3.58 (bs, $3 \mathrm{H}$ ), 3.37 (s, 2H) ppm. Anal. Calcd for $\mathrm{C}_{13} \mathrm{H}_{17} \mathrm{IN} \mathrm{N}_{3} \mathrm{O}: \mathrm{C}, 43.57 ; \mathrm{H}, 4.79$, N, 11.73. Found: C,43.38; H, 4.62; N, 11.46.

3-Methyl-1-[(2,2-dimethylpropionyl)methylamino]-3H-imidazol-1-ium iodide (3d). White prisms from EtOH; mp 176-177 ${ }^{\circ} \mathrm{C}$. IR (KBr) 3134, 3045, 2997, 1676, 1579, 1473, 1299, $1086 \mathrm{~cm}^{-1}$; ${ }^{1} \mathrm{H}-\mathrm{NMR}$ (DMSO-d, 300 $\mathrm{MHz}): \delta 9.57(\mathrm{~s}, 1 \mathrm{H}), 8.10(\mathrm{~s}, 1 \mathrm{H}), 7.83(\mathrm{~s}, 1 \mathrm{H}), 3.91(\mathrm{~s}, 3 \mathrm{H}), 3.55(\mathrm{~s}, 3 \mathrm{H}), 1.22(\mathrm{~s}, 9 \mathrm{H}) \mathrm{ppm}$. Anal. Calcd for $\mathrm{C}_{10} \mathrm{H}_{18} \mathrm{IN}_{3} \mathrm{O}: \mathrm{C}, 37.17 ; \mathrm{H}, 5.61 ; \mathrm{N}, 13.00$. Found: $\mathrm{C}, 37.17 ; \mathrm{H}, 5.61 ; \mathrm{N}, 13.18$.

1-(Hexadecanoylmethylamino)-3-methyl-3H-imidazol-1-ium iodide (3e). White plates from $\mathrm{Et}_{2} \mathrm{O} / \mathrm{EtOAc}$; $\operatorname{mp~77-79}{ }^{\circ} \mathrm{C}$. IR (KBr) 3076, 2918, 2851, 1700, 1580, 1466, 1385, $1129 \mathrm{~cm}^{-1} ;{ }^{1} \mathrm{H}-\mathrm{NMR}$ (DMSO-d 6 , 300 MHz): $\delta 9.90(\mathrm{bs}, 1 \mathrm{H}), 7.61(\mathrm{~s}, 1 \mathrm{H}), 7.57(\mathrm{~s}, 1 \mathrm{H}), 4.14(\mathrm{~s}, 3 \mathrm{H}), 3.71(\mathrm{~s}, 3 \mathrm{H}), 2.42-2.48(\mathrm{~m}, 2 \mathrm{H}), 1.60-1.64(\mathrm{~m}, 2 \mathrm{H}), 1.20-$ 
$1.40(\mathrm{~m}, 24 \mathrm{H}), 0.85(\mathrm{t}, \mathrm{J}=6.6 \mathrm{~Hz}, 3 \mathrm{H}) \mathrm{ppm}$. Anal. Calcd for $\mathrm{C}_{21} \mathrm{H}_{40} \mathrm{IN}_{3} \mathrm{O} . \mathrm{H}_{2} \mathrm{O}: \mathrm{C}, 50.91 ; \mathrm{H}, 8.54, \mathrm{~N}, 8.48$. Found: C,51.05; H, 8.57; N, 8.54 .

1-[(1-Isoquinolinecarbonyl)methylamino)]-3-methyl-3H-imidazol-1-ium iodide (3h). Brown plates from acetone; mp 119-121 ${ }^{\circ} \mathrm{C}$. IR (KBr) 3067, 2951, 2868, 1627, 1566, 1458, 1339, $1101 \mathrm{~cm}^{-1}$; ${ }^{1} \mathrm{H}-\mathrm{NMR}$ (DMSO-d ${ }_{6}$, $300 \mathrm{MHz}) 89.65(\mathrm{~s}, 1 \mathrm{H}), 8.67(\mathrm{~d}, \mathrm{~J}=6.6 \mathrm{~Hz}, 1 \mathrm{H}), 8.47-8.52(\mathrm{~m}, 2 \mathrm{H}), 8.32(\mathrm{~d}, \mathrm{~J}=7.7 \mathrm{~Hz}, 1 \mathrm{H}), 8.22(\mathrm{dd}, \mathrm{J}=6.6$, $8.1 \mathrm{~Hz}, 1 \mathrm{H}), 8.01(\mathrm{dd}, \mathrm{J}=7.7$ and $8.1 \mathrm{~Hz}, 1 \mathrm{H}), 7.87(\mathrm{~s}, 1 \mathrm{H}), 7.66(\mathrm{~s}, 1 \mathrm{H}), 4.44(\mathrm{~s}, 3 \mathrm{H}), 3.88(\mathrm{~s}, 3 \mathrm{H}) \mathrm{ppm}$. Anal. Calcd for $\mathrm{C}_{15} \mathrm{H}_{15} \mathrm{IN}_{4} \mathrm{O}: \mathrm{C}, 45.68 ; \mathrm{H}, 3.84 ; \mathrm{N}, 14.22$. Found: $\mathrm{C}, 45.52 ; \mathrm{H}, 3.95 ; \mathrm{N}, 14.03$.

1-[(4-Benzoylbutyryl)methylamino]-3-methyl-3H-imidazol-1-ium iodide (3i). White powder from EtOH; mp $164-166^{\circ} \mathrm{C}$. IR (KBr) 3139, 3055, 2973, 1678, 1636, 1572, 1443, 1384, 1309, 1255, 1199, 1118, $1059 \mathrm{~cm}^{-1}$; ${ }^{1} \mathrm{H}-\mathrm{NMR}\left(\mathrm{CD}_{3} \mathrm{OD}, 300 \mathrm{MHz}\right)$ 7.97-8.00 (m, 2H), $7.89(\mathrm{bs}, 1 \mathrm{H}), 7.72(\mathrm{bs}, 1 \mathrm{H}), 7.57-7.62(\mathrm{~m}, 1 \mathrm{H}), 7.46-7.51(\mathrm{~m}$, $2 \mathrm{H}), 4.02(\mathrm{~s}, 3 \mathrm{H}), 3.58(\mathrm{~s}, 3 \mathrm{H}), 3.08-3.20(\mathrm{~m}, 2 \mathrm{H}), 2.40-2.72(\mathrm{~m}, 2 \mathrm{H}), 1.98-2.10(\mathrm{~m}, 2 \mathrm{H}) \mathrm{ppm}$. Anal. Calcd for $\mathrm{C}_{16} \mathrm{H}_{20} \mathrm{IN}_{3} \mathrm{O}_{2}: \mathrm{C}, 46.50 ; \mathrm{H}, 4.88 ; \mathrm{N}, 10.17$. Found: $\mathrm{C}, 46.52 ; \mathrm{H}, 4.95 ; \mathrm{N}, 10.03$.

3-Methyl-1-[methyl(2-thiopheneacetyl)amino]-3H-imidazol-1-ium iodide (3j). White powder from EtOH; mp 149-151 ${ }^{\circ} \mathrm{C}$. IR (KBr) 3140, 3088, 1696, 1651, 1580, 1547, 1471, 1441, 1401, 1372, 1352, 1278, 1208, 1107 , $1075 \mathrm{~cm}^{-1}$; ${ }^{1} \mathrm{H}-\mathrm{NMR}$ (DMSO-d ${ }_{6}, 300 \mathrm{MHz}$ ) 9.49 (bs, 1H), 8.02 (bs, 1H), $7.83(\mathrm{~s}, 1 \mathrm{H}), 7.42-7.44(\mathrm{~m}, 1 \mathrm{H}), 6.86-$ $7.00(\mathrm{~m}, 2 \mathrm{H}), 4.20(\mathrm{bs}, 2 \mathrm{H}), 3.89(\mathrm{~s}, 3 \mathrm{H}), 3.49(\mathrm{bs}, 3 \mathrm{H}) \mathrm{ppm}$. Anal. Calcd for $\mathrm{C}_{11} \mathrm{H}_{14} \mathrm{IN}{ }_{3} \mathrm{OS}: \mathrm{C}, 36.38 ; \mathrm{H}, 3.89 ; \mathrm{N}$, 11.57. Found: C, 36.22; H, 3.83; N, 11.39 .

Synthesis of bis-amides 8. General procedure. Method A. To a mixture of the corresponding dicarboxylic acid $(1.68 \mathrm{mmol})$ and $5(0.80 \mathrm{~g}, 3.36 \mathrm{mmol})$ in pyridine $(7.5 \mathrm{~mL}), 6(0.720 \mathrm{~g}, 3.36 \mathrm{mmol})$ was added dropwise with stirring at $0^{\circ} \mathrm{C}$.The reaction mixture was stirred at room temperature overnight and then an aqueous solution of $\mathrm{K}_{2} \mathrm{CO}_{3}(0.92 \mathrm{~g}, 6.7 \mathrm{mmol})$ was added dropwise. The solvent was evaporated under reduced pressure, $\mathrm{CH}_{2} \mathrm{Cl}_{2}$ was added and the mixture was filtered through celite and the filtrate was concentrated under reduced pressure. The residue was purified by column chromatography (acetone:MeOH, 5:1) giving pure bis-amides.

Method B. Following method A, the reaction of the corresponding dicarboxylic acid ( $1.68 \mathrm{mmol})$ and $4(0.80$ $\mathrm{g}, 3.36 \mathrm{mmol}$ ) afforded bis-aminides 7 after elimination of the solvent under reduced pressure. To a suspension of crude 7 in acetone, methyl iodide $(1.9 \mathrm{~g}, 13.44 \mathrm{mmol})$ was added and the mixture was refluxed for $12 \mathrm{~h}$. The precipitate formed was filtered and recrystallised to give pure bis-amides.

1,1'-[1,7-Dimethyl(1,7-diaza-2,6-diaxo-hepta-1,7-diyl) bis-(3-methyl-3H-imidazol-1-ium) diiodide (8a). White prisms from EtOH; 59\% (method A), 53\% (method B); mp 189-190 ${ }^{\circ} \mathrm{C}$. IR (KBr) 3142, 3099, 3059, 1707, 1576, 1213, $1033 \mathrm{~cm}^{-1} .{ }^{1} \mathrm{H}-\mathrm{NMR}$ (DMSO-d $\mathrm{d}_{6}, 300 \mathrm{MHz}$ ): 89.46 (bs, 2H), 8.00 (bs, 2H), 7.82 (s, 2H), 3.89 (s, 6H), 3,42 (s, 6H), 2.0-2.5 (m, 4H), 1.7-1.8 (m, 2H) ppm. MS (EI, $70 \mathrm{eV}$ ) m/z 194 (43), 142 (100), 127 (46), 96 (16). Anal. Calcd for $\mathrm{C}_{15} \mathrm{H}_{24} \mathrm{I}_{2} \mathrm{~N}_{6} \mathrm{O}_{2}: \mathrm{C}, 31.38 ; \mathrm{H}, 4.21 ; \mathrm{N}, 14.64$. Found: $\mathrm{C}, 31.48 ; \mathrm{H}, 4.42 ; \mathrm{N}, 14.73$. 
1,1'-[1,10-Dimethyl(1,10-diaza-2,9-dioxo-deca-1,10-diyl) bis-(3-methyl-3H-imidazol-1-ium)] diiodide (8b): White prisms from EtOH; 67\% (method A), 58\% (method B); mp 197-199 ${ }^{\circ} \mathrm{C}$. IR (KBr) 3071, 2940, 1698 , 1677, 1548, 1468, $1121 \mathrm{~cm}^{-1}$. ${ }^{1} \mathrm{H}-\mathrm{NMR}$ (DMSO-d ${ }_{6}, 300 \mathrm{MHz}$ ): $\delta 9.46$ (bs, 2H), 8.00 (bs, 2H), 7.89 (s, $2 \mathrm{H}$ ), 3.89 $(\mathrm{s}, 6 \mathrm{H}), 3.42$ (s, 6H), 2.44 (bs, $4 \mathrm{H}), 1.49$ (bs, $4 \mathrm{H}), 1.26$ (bs, $4 \mathrm{H}) \mathrm{ppm}$. Anal. Calcd for $\mathrm{C}_{18} \mathrm{H}_{30} \mathrm{I}_{2} \mathrm{~N}_{6} \mathrm{O}_{2}: \mathrm{C}, 35.06 ; \mathrm{H}$, 4.91; N, 13.64. Found: C, 35.01; H, 4.65; N, 13.43 .

1,1'-[1,11-Dimethyl-(1,11-diaza-2,10-dioxo-undeca-1,11-diyl) bis-(3-methyl-3H-imidazol-1-ium)] diiodide (8c): White powder from EtOH; 60\% (method A), $61 \%(\operatorname{method} \mathrm{B}) ; \operatorname{mp} 167-169^{\circ} \mathrm{C}$. IR (KBr) 3059, 2943, 1700 , 1553, 1468, $1121 \mathrm{~cm}^{-1}$. ${ }^{1} \mathrm{H}-\mathrm{NMR}$ (DMSO-d, $\left.300 \mathrm{MHz}\right) \delta 9.49(\mathrm{bs}, 2 \mathrm{H}), 8.00(\mathrm{bs}, 2 \mathrm{H}), 7.81(\mathrm{~s}, 2 \mathrm{H}), 3.88(\mathrm{~s}, 6 \mathrm{H})$, $3.40(\mathrm{~s}, 6 \mathrm{H}), 2.2$ (bs, $4 \mathrm{H}), 1.47$ (bs, $4 \mathrm{H}), 1.22$ (bs, $4 \mathrm{H}), 1.00-1.11(\mathrm{~m}, 2 \mathrm{H}) \mathrm{ppm}$. Anal. Calcd for $\mathrm{C}_{19} \mathrm{H}_{32} \mathrm{I}_{2} \mathrm{~N}_{6} \mathrm{O}_{2}: \mathrm{C}_{\text {, }}$ $36.19 ; \mathrm{H}, 5.12 ; \mathrm{N}, 13.13$. Found: C, 35.91; H, 4.95; N, 13.03.

1,1'-[N,N'-Dimethylisophtalamido) bis-(3-methyl-3H-imidazol-1-ium)] diiodide (8d). White prisms from EtOH; 63\% (method A); mp 220-221 ${ }^{\circ} \mathrm{C}$. IR (KBr) 3138, 3075, 2921, 1690, 1480, 1275, 1187, $1093 \mathrm{~cm}^{-1}$. ${ }^{1} \mathrm{H}-\mathrm{NMR}$ (DMSO-d $\left._{6}, 300 \mathrm{MHz}\right) \delta 9.58(\mathrm{~s}, 2 \mathrm{H}), 8.10(\mathrm{~s}, 2 \mathrm{H}), 7.77(\mathrm{~s}, 2 \mathrm{H}), 7.70(\mathrm{~s}, 4 \mathrm{H}), 3.88(\mathrm{~s}, 6 \mathrm{H}), 3.48(\mathrm{~s}, 6 \mathrm{H}) \mathrm{ppm}$. Anal. Calcd for $\mathrm{C}_{18} \mathrm{H}_{22} \mathrm{I}_{2} \mathrm{~N}_{6} \mathrm{O}_{2}: \mathrm{C}, 35.53 ; \mathrm{H}, 3.65 ; \mathrm{N}, 13.82$. Found: $\mathrm{C}, 35.34 ; \mathrm{H}, 3.53 ; \mathrm{N}, 14.19$.

Dimethylterephtalamido) bis-(3-methyl-3H-imidazol-1-ium) diiodide (8e) White prisms from EtOH; 70\% (method A), 63\% (method B); mp 272-174 ${ }^{\circ} \mathrm{C}$ (decomposition). IR (KBr) 3138, 3048, 2984, 2983, 1684, 1606, 1547, 1204, 1182, $1092 \mathrm{~cm}^{-1} ;{ }^{1} \mathrm{H}-\mathrm{NMR}$ (DMSO-d $6,300 \mathrm{MHz}$ ): $\delta 9.87(\mathrm{~s}, 2 \mathrm{H}), 8.44(\mathrm{~s}, 1 \mathrm{H}), 8.16(\mathrm{~s}, 2 \mathrm{H}), 7.87-7.93$ $(\mathrm{m}, 2 \mathrm{H}), 7.72-7.80(\mathrm{~m}, 3 \mathrm{H}), 3.89(\mathrm{~s}, 6 \mathrm{H}), 3.49(\mathrm{~s}, 6 \mathrm{H}) \mathrm{ppm}$. Anal. Calcd for $\mathrm{C}_{18} \mathrm{H}_{22} \mathrm{I}_{2} \mathrm{~N}_{6} \mathrm{O}_{2}: \mathrm{C}, 35.53 ; \mathrm{H}, 3.65 ; \mathrm{N}$, 13.82. Found: C, $35.47 ; \mathrm{H}, 3.53 ; \mathrm{N}, 14.19$.

Synthesis of ketones 12. General procedure. To a suspension of the salt $3(0.5 \mathrm{mmol})$ in $5 \mathrm{~mL}$ of THF at $0^{\circ} \mathrm{C}$, the corresponding organolithium (or Grignard reagent) $(0.5 \mathrm{mmol})$ was added and the resulting reaction mixture was stirred for $30 \mathrm{~min}$ and then allowed to warm to room temperature. The reaction mixture was quenched with $1 \mathrm{~mL}$ of $\mathrm{NH}_{4} \mathrm{Cl}$ solution and partitioned between a 1:1 mixture of water and diethyl ether $(30 \mathrm{~mL})$. The aqueous layer was extracted with $\mathrm{EL}_{2} \mathrm{O}(3 \times 10 \mathrm{~mL})$ and the combined organic extracts were dried over $\mathrm{Na}_{2} \mathrm{SO}_{4}$ and concentrated under reduced pressure. Purification of the crude product by passing through a short column (hexane/ethyl acetate, 9:1) gave pure ketones 12. The amide 3 can also be metalated using LDA (0.55 mmol, 2 $\mathrm{M}$ solution in THF) at $0^{\circ} \mathrm{C}$ for $30 \mathrm{~min}$. Subsequent addition of the organometallic $(0.5 \mathrm{mmol})$ gave identical results.

1-(4-Methylphenyl)-2-phenylethanone (12a) is described in ref. 11;1-phenyl-2-hexanone (12b) is described in ref 12; 2,2-dimethylpropiophenone (12c) is described in ref. 13; 2,2,4,4-tetramethyl-3-pentanone (12e) is described in ref. $14 ; 1$-(2'-thienyl)-2,2-dimethyl-propanone (12f) is described in ref. 15; 2,2-dimethylhex-4-yn-3-one (12g) is described in ref. 16 .

2,2-Dimethyl-3-octadecanone (12d): White needles from hexane; $\mathrm{mp} 34-36^{\circ} \mathrm{C}$. IR (neat) $2921,2852,1705$, $1462,1269 \mathrm{~cm}^{-1} ;{ }^{1} \mathrm{H}-\mathrm{NMR}\left(300 \mathrm{MHz}, \mathrm{CDCl}_{3}\right) \delta 2.34(\mathrm{t}, \mathrm{J}=7.3 \mathrm{~Hz}, 2 \mathrm{H}), 1.60-1.65(\mathrm{~m}, 2 \mathrm{H}), 1.19-1.30(\mathrm{~m}, 3 \mathrm{H})$, $0.88(\mathrm{t}, \mathrm{J}=6.9 \mathrm{~Hz}, 3 \mathrm{H}) \mathrm{ppm}$. Anal. Calcd. for $\mathrm{C}_{20} \mathrm{H}_{40} \mathrm{O}: \mathrm{C}, 81.01 ; \mathrm{H}, 13.60$. Found: $\mathrm{C}: 80.76 ; \mathrm{H}: 13.40$. 
Synthesis of aldehydes 13. General procedure. A solution of the salt $3(0.5 \mathrm{mmol})$ in THF ( $2 \mathrm{~mL})$ was cooled to $-10^{\circ} \mathrm{C}$ and treated with $0.55 \mathrm{mmol}(1 \mathrm{M}$ in THF) of DIBALH under argon. The mixture was allowed to warm to room temperature over $30 \mathrm{~min}$ and then quenched with $5 \%$ hydrochloric acid $(1 \mathrm{~mL})$. The mixture was diluted with water $(10 \mathrm{~mL})$ and extracted with $\mathrm{Et}_{2} \mathrm{O}(3 \times 10 \mathrm{~mL})$. The organic phase was dried $\left(\mathrm{Na}_{2} \mathrm{SO}_{4}\right)$, filtered and concentrated under reduced pressure to give a residue which was purified by column chromatography on silica gel (petroleum ether/ EtOAc, 9:1) to afford the pure aldehyde.

Synthesis of $\alpha$-alkylated ketones 14. General Procedure. To a solution of the salt $3 \mathrm{c}(0.5 \mathrm{mmol})$ in THF ( 5 $\mathrm{mL})$ at $-20^{\circ} \mathrm{C}$, was added dropwise LDA $(1.1 \mathrm{mmol}, 2 \mathrm{M}$ solution in THF) and the resulting reaction mixture was stirred for $30 \mathrm{~min}$. The electrophile $(1.1 \mathrm{mmol})$ was then added at $-20^{\circ} \mathrm{C}$ and the mixture was allowed to warm to $0{ }^{\circ} \mathrm{C}$. The corresponding organolithium reagent $(0.5 \mathrm{mmol})$ was added and the mixture was allowed to warm to room temperature. The reaction mixture was quenched with $1 \mathrm{~mL}^{\circ} \mathrm{NH}_{4} \mathrm{Cl}$ solution and partitioned between a 1:1 mixture of water and diethyl ether $(30 \mathrm{~mL})$. The aqueous layer was extracted with $\mathrm{Et}_{2} \mathrm{O}(3 \times 10 \mathrm{~mL})$ and the combined organic extracts were dried over $\mathrm{Na}_{2} \mathrm{SO}_{4}$ and concentrated under reduced pressure. Purification of the crude product by passing through a short column (hexane/ethyl acetate, 9:1) gave the alkylated ketones 14.

1-(4-Methylphenyl)-2-phenyl-1-propanone (14a) is described in ref. 17.

1,2-Diphenyl-4-hexyn-3-one (14b). White cubes from hexane; mp 82-83 ${ }^{\circ} \mathrm{C}$. IR (KBr) 3060, 3026, 2938, $2216,1664,1492,1448,1290,1250,1153,1070 \mathrm{~cm}^{-1} ;{ }^{1} \mathrm{H}-\mathrm{NMR}\left(\mathrm{CDCl}_{3}, 300 \mathrm{MHz}\right)$ 8.7.15-7.31 (m, 8H), 7.06-7.08 $(\mathrm{m}, 2 \mathrm{H}), 4.02(\mathrm{t}, \mathrm{J}=7.3 \mathrm{~Hz}, 1 \mathrm{H}), 3.51(\mathrm{dd}, \mathrm{J}=7.3,13.9 \mathrm{~Hz}, 1 \mathrm{H}), 3.00(\mathrm{dd}, \mathrm{J}=7.3,13.9 \mathrm{~Hz}, 1 \mathrm{H}), 1.92(\mathrm{~s}, 3 \mathrm{H})$ ppm; MS (CI, $70 \mathrm{eV}) \mathrm{m} / \mathrm{z} 249\left(\mathrm{M}^{+}+1,100\right), 248\left(\mathrm{M}^{+}, 7\right), 181$ (7), 91 (5). Anal. Calcd. for $\mathrm{C}_{18} \mathrm{H}_{16} \mathrm{O}: \mathrm{C}, 87.06 ; \mathrm{H}$, 6.81. Found: C:87.06; H: 6.49 .

4-Phenyl-1-nonen-5-one (14c). Colourless oil; IR (KBr) 3029, 2927, 1732, 1713, 1644, 1599, 1489, 1455 , $1155,1097 \mathrm{~cm}^{-1} .{ }^{1} \mathrm{H}-\mathrm{NMR}\left(\mathrm{CDCl}_{3}, 300 \mathrm{MHz}\right)$ 8 7.12-7.38 (m, 5 H), 5.51-5.57 (m, $\left.1 \mathrm{H}\right), 4.80-5.24(\mathrm{~m}, 2 \mathrm{H}), 4.02$ (m, $1 \mathrm{H}), 3.60-3.72(\mathrm{~m}, 1 \mathrm{H}), 2.70-2.86(\mathrm{~m}, 1 \mathrm{H}), 2.43(\mathrm{t}, \mathrm{J}=7.3 \mathrm{~Hz}, 1 \mathrm{H}), 1.66(\mathrm{~m}, 2 \mathrm{H}), 1.57(\mathrm{~m}, 2 \mathrm{H}), 0.89$ (t, $\mathrm{J}=7.3 \mathrm{~Hz}, 3 \mathrm{H})$. MS (CI, $70 \mathrm{eV}) \mathrm{m} / \mathrm{z} 217\left(\mathrm{M}^{+}+1,100\right), 216\left(\mathrm{M}^{+}, 18\right), 159(89)$, 131(54). Anal. Calcd. for: $\mathrm{C}_{15} \mathrm{H}_{20} \mathrm{O}:$ C, 83.27 ; H, 9.33. Found: C:82.96; H: 9.31 .

1-(4-Methylphenyl)-2-(2-thienyl)-1-propanone (14d). Yellow oil; IR (KBr) 2929, 2873, 1726, 1681, 1606, $1453,1374,1264,1232,1181,1120 \mathrm{~cm}^{-1}$. ${ }^{1} \mathrm{H}-\mathrm{NMR}\left(\mathrm{CDCl}_{3}, 300 \mathrm{MHz}\right) \delta 7.90(\mathrm{~d}, \mathrm{~J}=8.0 \mathrm{~Hz}, 2 \mathrm{H}), 7.23(\mathrm{~d}, \mathrm{~J}=8.0$ $\mathrm{Hz}, 2 \mathrm{H}), 7.16(\mathrm{~d}, \mathrm{~J}=4.8 \mathrm{~Hz}, 1 \mathrm{H}), 6.87-6.99(\mathrm{~m}, 2 \mathrm{H}), 4.98(\mathrm{q}, \mathrm{J}=6.9 \mathrm{~Hz}, 1 \mathrm{H}), 2.38(\mathrm{~s}, 3 \mathrm{H}), 1.60(\mathrm{~d}, \mathrm{~J}=6.9 \mathrm{~Hz}$, 3H) ppm; MS (CI, $70 \mathrm{eV}) \mathrm{m} / 2231\left(\mathrm{M}^{+}+1,100\right), 205$ (16), 119 (26). Anal. Calcd. for: $\mathrm{C}_{14} \mathrm{H}_{14} \mathrm{OS}: \mathrm{C}, 73.02 ; \mathrm{H}, 6.13$. Found: C:73.06; H: 6.04 .

1-Hydroxy-1-(4-methoxy-phenyl)-2-thiophen-2-yl-hex-4-yn-3-one (14e). White prisms from hexane; mp 73-74 ${ }^{\circ} \mathrm{C}$. IR (KBr) 3373, 2923, 2850, 2251, 1711, 1602, 1487, 1460, 1317, 1243, 1134, $1054 \mathrm{~cm}^{-1} .{ }^{1} \mathrm{H}-\mathrm{NMR}$ 
$\left(\mathrm{CDCl}_{3}, 300 \mathrm{MHz}\right)$ 8 7.24-7.29 (m, 2H), 7.04-7.11 (m, 3H), 6.84-6.87 (m, 2H), 6.41 (m, 1H), $5.49(\mathrm{~m}, 1 \mathrm{H}), 5.16$ (m, 1H), $3.84(\mathrm{~s}, 3 \mathrm{H}), 1.97(\mathrm{~s}, 3 \mathrm{H}) \mathrm{ppm}$; MS (CI, $70 \mathrm{eV}) \mathrm{m} / \mathrm{z} 301\left(\mathrm{M}^{+}+1,2\right), 279(16), 231(9), 205$ (12), $160(16)$, 159 (100), 119 (20). Anal. Calcd. for $\mathrm{C}_{17} \mathrm{H}_{16} \mathrm{O}_{3} \mathrm{~S}: \mathrm{C}, 67.98 ; \mathrm{H}, 5.37$. Found: C:68.06; $\mathrm{H}: 5.42$.

Synthesis of diketones 15. General procedure. To a suspension of the bis-amide $8(0.5 \mathrm{mmol})$ in $5 \mathrm{~mL}$ of THF at $0^{\circ} \mathrm{C}$, was added dropwise LDA (1.1 mmol, $2 \mathrm{M}$ solution in THF) and the resulting reaction mixture was stirred for $30 \mathrm{~min}$. The corresponding organometallic reagent $(1.1 \mathrm{mmol})$ was then added and the mixture was allowed to warm to room temperature. The reaction mixture was quenched with $1 \mathrm{~mL}$ of $\mathrm{NH}_{4} \mathrm{Cl}$ solution and partitioned between a 1:1 mixture of water and diethyl ether $(30 \mathrm{~mL})$. The aqueous layer was extracted with diethyl ether $(3 \times 10 \mathrm{~mL})$ and the combined organic extracts were dried over $\mathrm{Na}_{2} \mathrm{SO}_{4}$ and concentrated under reduced pressure. Purification of the crude product by passing through a short column (hexane/ethyl acetate, 9:1) gave the pure diketones 15. Similar results were obtained by using 4 equiv of the organometallic instead of LDA (2.1 equiv) followed by organometallic addition ( 2 equiv).

1,8-Bis(4-methylphenyl)-1,8-octanedione (15b) is described in ref. 18;1,1'-(1,3-phenylene) bis(1-pentanone) (15c) is described in ref. 19.; 5,9-tridecadione (15d) is described in ref 20.; 1,4-phenylene bis[(4-methylphenyl)methanone] (15e) is described in ref. 21.

1,9-Diphenyl-1,9-nonadiyn-3,7-dione (15a): brown powder from hexane; mp 49-50 ${ }^{\circ} \mathrm{C}$; IR (KBr) 3062,2893 , 2199, 1683, 1443, 1373, 1280, 1072, 1042, $686 \mathrm{~cm}^{-1} ;{ }^{1} \mathrm{H}-\mathrm{NMR}\left(\mathrm{CDCl}_{3}, 300 \mathrm{MHz}\right) \delta$ 7.54-7.57 (m, $\left.4 \mathrm{H}\right), 7.42-7.46$ $(\mathrm{m}, 2 \mathrm{H}), 7.33-7.39(\mathrm{~m}, 4 \mathrm{H}), 2.79(\mathrm{t}, \mathrm{J}=7.3 \mathrm{~Hz}, 4 \mathrm{H}), 2.15(\mathrm{~m}, 2 \mathrm{H}) \mathrm{ppm}$. Anal. Caicd for $\mathrm{C}_{21} \mathrm{H}_{16} \mathrm{O}_{2}: \mathrm{C}, 83.97 ; \mathrm{H}$, 5.37. Found: C, 83.64; H: 5.67 .

Synthesis of dialdehydes 16. General procedure. A solution of the bis-amide $8(0.5 \mathrm{mmol})$ in $\mathrm{CH}_{2} \mathrm{Cl}_{2}(2 \mathrm{~mL})$ was cooled to $-10^{\circ} \mathrm{C}$ and treated with $1.1 \mathrm{mmol}(1 \mathrm{M}$ in THF) of DIBALH under argon. The mixture was allowed to warm to room temperature over $30 \mathrm{~min}$ and then quenched with $5 \%$ hydrochloric acid $(1 \mathrm{~mL})$. The mixture was diluted with water $(10 \mathrm{~mL})$ and extracted with $\mathrm{Et}_{2} \mathrm{O}(3 \times 10 \mathrm{~mL})$. The organic phase was dried $\left(\mathrm{Na}_{2} \mathrm{SO}_{4}\right)$ filtered and concentrated in vacuo to give a residue which was purified by column chromatography on silica gel (petroleum ether/ EtOAc, 9:1) to afford pure dialdehydes.

Acknowledgment. The authors acknowledge the Comisió Interdepartamental de Recerça i Innovació Tecnologica (CIRIT, project QFN94-4619) for financial support and the Ministerio de Educación y Ciencia for a studentship (M.A.H.).

\section{REFERENCES}

1. Martinez, Y.; Heras, M. A.; Vaquero, J. J.; García, J. L.; Alvarez-Builla, J. Tetrahedron Lett. 1995, $36,8513$. 
2. Heras, M. A.; Molina, A.; Vaquero, J. J.; García, J. L.; Alvarez-Builla, J. J. Org. Chem. 1993, 58, 5862.

3. Heras, M. A.; Vaquero, J. J.; García, J. L.; Alvarez-Builla, J. Tetrahedron Lett. 1995, 36, 455.

4. (a) Nahm, S.; Weinreb, S. M. Tetrahedron Lett. 1981, 56, 291. (b) ONeill, B. T. In Comprehensive Organic Synthesis, 1991, Vol. 1, p 397.(a) Sibi, M. P. Org. Prep. Proced. Int. 1993, 25, 15

5. For recent applications see: .(a) Evans, D. A.; Gauchet-Prunet, J. A. J. Org. Chem. 1993, 58, 2446. (b) Sibi, P. M. Marvin, M.; Sharma., R. J. Org. Chem. 1995, 60, 5016. (c) Sibi, M. P.; Christensen, J. W.; Kim, S.-G.; Eggen, M. J.; Stessman, C.; Oien, L. Tetrahedron Lett. 1995, 36, 6209. (d) Williams, J. M.; Jobson, R. B.; Yasuda, N.; Marchesini, G.; Dolling, U.-H.; Grabowski, J.J. Tetrahedron Lett. 1995, 36, 5461. (e) Sawamura, M.; Hamashima, H.; Shinoto, H.; Ito, Y. Tetrahedron Lett. 1995, 36, 64479. (f) Davies, S. G.; McCarthy, T. D. Synlett. 1995, 700. (g) Braslau, R.; Naik, N.; Olmstead, M. M.; J. Org. Chem., 1996, 61, 368.

6. Klausner, Y. S.; Bodansky, M. Synthesis, 1972, 453.

7. Sun-ichi, Y.; Yutaka, K.; Takayuki, S. Tetrahedron Lett. 1973, 18, 1595.

8. Kimura, H.; Konno, H.; Takahashi, N. 1993, 66, 327.

9. For recent examples of the syntheses of 1,2-diketones by reacting amides and organometallics, see: (a) MuellerWesterhoff, U. T.; Zhou, M. Tetrahedron Lett., 1993, 34, 571. (b) Mueller-Westerhoff, U. T.; Zhou, M. J. Org. Chem. 1993, 34, 571.

11. Katritzky, A. R.; Kuzmierkiewicz, W. J. Chem. Soc. Perkin Trans. I, 1987, 819.

12. Meyers, A. I.; Smith, E. M. J. Org. Chem. 1972, 37, 4289.

13. Millard, A. A.; Rathke, W. J. Org. Chem. 1978, 43, 1834.

14. Dubois, J. E.; Zhang, B. L.; Lion, C. Tetrahedron, 1981, 37, 4189.

15. Yur'ev, Y. K.;Belyakova, Z. V.; Volkov, V. P. Zhur. Obshchei. Khim. 1959, 29, 3873-3880. C.A. 1959, 54, $20824 \mathrm{i}$.

16. Saba, S.; Wolff, S.; Schröder, C.; Margaretha, P.; Agosta, W. C. J. Am. Chem. Soc. 1983, 105, 6902.

17. Lasperas, M.; Pérez-Rubalcaba, A.; Quiroga-Feijoo, M. Tetrahedron, 1980, 36, 3403.

18. Duhkhaharan, C.; Minati, S. Sci. Cult. 1969, 35, 333.

19. Wagner, P. J.; Siebert, E. J. J. Am. Chem. Soc., 1981, 103, 7329.

20. Owsley, D. C ; Nelke, J. M.; Bloomfield, J. J. J. Org. Chem. 1973, 38, 901.

21. Lee, W. Y.; Moon, B. G.; Park, C. H.; Bang, S. H.; Lee, J. H. Bull. Korean Chem. Soc. 1988, 9, 325.

(Received in UK 5 August 1996; revised 20 September 1996; accepted 26 September 1996) 